\title{
Homelessness and Housing Market Condition in the United States
}

\author{
Praopan Pratoomchat \\ Assistant Professor of Economics, University of Wisconsin-Superior, Superior, Wisconsin, USA, ppratoom@uwsuper.edu
}

ABSTRACT: The study estimated the relationship between the homelessness rates, the housing market factors, and the socio-economic factors in the country level, regional level, and the state level in the United States from 2007 to 2016. The results show that the housing price index, personal expenditure on housing utilities, rental vacancy rate, poverty rate, number of job loss and income inequality are significant determinants of the homelessness in the country level. For the regional level, the West had the highest homelessness rate intercept while the South West is the region with the lowest intercept. Housing price, the expenditure on housing utilities and poverty rate are the factors determining the homelessness rate in the regional level. When the study adds the fixed effects of fifty states to the model, the result shows that rental vacancy rate, number of job loss and the income inequality are three factors that can explain the change in homeless population number in the state level. To slow down the growing homelessness in the country level, the economic policy should be focusing at poverty reduction, healing people who suffered from job loss, and changing the tax policy to increase income equality. For the housing market, the government may consider the policy to support the expansion of low-cost housing units in term of both fiscal and monetary policies.

KEYWORDS: Homeless, Housing, Economic Policy

\section{Introduction}

Homelessness in the U.S. increased for the first time after 2010 by $0.7 \%$ in 2017 and increased slightly again by $0.3 \%$ in 2018 . The largest increases were among children and young adults. The number was considered to be driven by more people living on the streets in the West Coast Cities (Associated Press 2018). Rents in the U.S. have increased beyond affordability for the extremely poor families especially in the big cities such as Los Angeles, Seattle, and San Diego. On a single night in the United State, there are an estimated 552,830 people experiencing homelessness (National Alliance to End Homelessness, 2018). Most of them were staying in emergency shelters, transitional housing program, or safe havens, and approximately $34 \%$ of them were in unsheltered locations such as streets or abandoned buildings. Figure 1 shows total number of people experiencing homelessness by type. Most of them are individuals. The rest are people with children, chronically homeless individuals, veterans, and youth. The majority of homeless people are white (79\%) and African American (40\%).

Some states in the U.S. were able to reduce number of homelessness rates while others are getting a lot worse. The highest homelessness rate was in Hawaii in 2016. There were 56 homeless individuals per 10,000. The lowest homelessness rate was in Mississippi in 2007 and 2016. In 2017, thirty states and Washington, D.C. reported decreases in overall homelessness, while 20 states reported increases. California reported the largest increase in the number of homeless following by New York (National Alliance to End Homelessness 2018).

Table 1. Top 5 Highest and Lowest \% Changes in Homelessness Rate (\%) in the U.S. by State

\begin{tabular}{|l|c|c|c|}
\hline State & $\%$ change & State & $\%$ change \\
\hline MI & $-67.1 \%$ & SD & $85.1 \%$ \\
\hline NJ & $-48.6 \%$ & WY & $59.6 \%$ \\
\hline KY & $-47.4 \%$ & DC & $57.0 \%$ \\
\hline WV & $-42.4 \%$ & ND & $45.1 \%$ \\
\hline TX & $-41.9 \%$ & NY & $37.9 \%$ \\
\hline
\end{tabular}

Source: U.S. Department of Housing and Urban Development (2018) 
According to Table 1, Michigan had the highest decreasing rate in total homelessness at $-67.1 \%$ while South Dakota had experienced the highest homelessness rates during 2007-2016 at $85.1 \%$, followed by Wyoming, Washington DC, North Dakota, New York, Hawaii, Massachusetts, Idaho and Mississippi.

Economic hardship and housing affordability are among important reasons of homelessness. Financial crisis in 2007-2009 led to a surge in foreclosures and unemployment rates in both rural and urban areas. After the crisis, the housing market started to recover. Although the housing price index after the crisis dropped to the lowest at 118.99 in 2012, it has increased after that until now. The Federal Housing Finance Agency reported that the annual house price index in 2017 was at 151.78, growing 5.67\% and had surpassed the level before the crisis in 2007. At the same time, the median gross rent increased from 2012-2016 according to the American Community Survey five-year estimate. Figure 2 shows that the rate of change in the house price index is climbing up to the level of the housing bubble before the economic crisis in 2007-2009. The median sale prices of the new houses in the U.S. after 2000 went up to a peak in 2007, then dropped during the financial crisis in 2008-2009. It started to pick up again in 2010.

Not everyone in the U.S. can afford to buy a house. The U.S. Census Bureau provides the rental vacancy rates which can be used to measure the percentage of all available rental units in a rental property, such as hotel or apartment complex, that are vacant or unoccupied. High vacancy rate indicates that a property is not renting well. The rental vacancy rate of the United States during 19892017 was peaked during the financial crisis. It had been dropping after the crisis until 2016. In 2017, however, it started to increase again for the first time to from 6.9 in 2016 to $7.2 \%$ in 2017 . As shown in Figure 1, 48.5\% of individuals who could not afford to buy a median-price home in 1984. It had increased to $56.7 \%$ in 2009 .

Figure 1. Affordability Status of Families and Unrelated Individuals for a Median-Priced Home, United States, 1984, 1988, 1991, 1993, 1995, 2002, 2004, and 2009

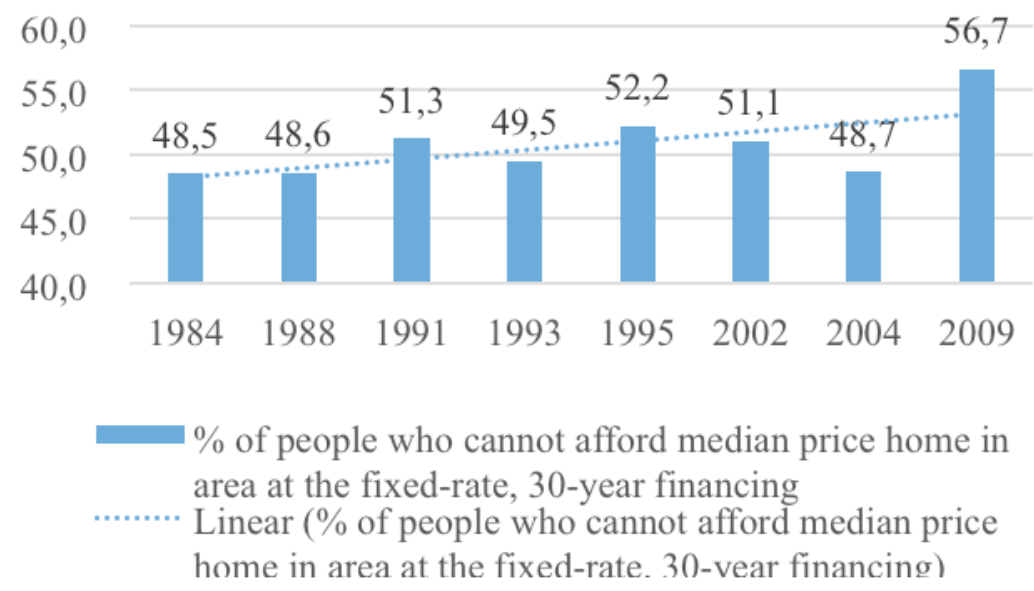

Source: U.S. Census Bureau, Survey of Income and Program Participation, Wave 4, 2008

Using the housing price index and rental vacancy rate, there is a possibility that the housing market now started to build up the bubble again. Too high housing prices and rents combined with the economic hardship and less supporting welfare from the government can lead to more homeless population on the streets. The objective of this study is to investigate the determinants of the U.S. homelessness across all states after the 2008 financial crisis using panel data. The study uses the factors in the housing market such as housing price, rental rates, housing stocks, rental stocks, and the housing affordability as the independent variables to determine the homelessness. This study provides a more comprehensive panel analysis of the homeless during the financial crisis (2007-2009) and after the crisis. The housing price index (2000 as the base year) is used to represent the change of prices in the overall housing market. The personal consumption expenditure on housing is used for the rental expenditures of a typical consumer in the U.S. The availability or supply of the housing units in each state is represented by the estimated number of housing units. The variable from the market for rentals is also included in the form of the rental 
vacancy rate. The author also incorporates the socio-economic factor of each state into the model. The technique used in the study is the panel least square method. There are three levels of the study: National, regional, and state levels.

The study's results confirm the main hypothesis that the variation of the homelessness rates in the U.S. from 2007 to 2016 can be explained by the variations of the housing price index, the rental expenditure, and the rental vacancy rate. The economic factors which are represented by the poverty rate, the numbers of job loss and inequality are also able to statistically explain the number of homeless people in the overall United States. For the regional level, housing price and the rental expenditure are two factors from the housing market that can explain the number of homeless population. The South East of the U.S. has the lowest average of homelessness intercept while the West has the highest homelessness intercept. For the state level, the rental vacancy rate and the number of housing units are the housing market factors that plays in the state level homelessness. Number of job loss and the inequality index are also significant determinants in this level.

\section{Literature Review}

The modern homelessness first rose in the early 1980s (O'Flaherty, 2002). Homeless individuals are present in small towns and rural areas as well as cities. Homelessness by definition of the U.S. department of Housing and Urban Development (2018) includes;

- People who are living in a place not meant for human habitation, in emergency shelter, in transitional housing or are exiting an institution where they temporarily resided

- People who are fleeing or attempting to flee domestic violence, have no other residence, and lack the resource or support network to obtain other permanent housing

- People who are losing their primary nighttime residence

- Families with children or unaccompanied youth are unstably house and continue in that state.

Although the house quality in the U.S. has been improved over time for the low income families, they are paying much larger share of their income for it (Malpezzi and Green, 1996). The result from Malpezzi and Green (1996) was confirmed by the result of Weicher's (1991), which showed that the number of families paying more than half of their income for rent increased from $24 \%$ to $36 \%$ from 1974 and 1987 . There are some literature focused at the improving quality and argue that the market has either corrected or is in the process of correcting the affordability of the housing. Lowry (1960) found that subsidized units will inevitably crowd-out low cost market rental units. The rent burden problem could represent an income problem more than a housing market problem.

There are two different types of empirical cross-section studies on the issue of the contemporary homelessness. The first group of the literature found that the housing market has a large influence on the homelessness, while the population composition usually does not. The first group of the literature look at homeless as the difference between the number of available homes and the number of household seeking housing. They suggest that some policy changes, deregulation, and interventions in the housing market can help reduce the homelessness. The second group which normally uses the individual observations found that the effects for housing market conditions of the cities are limited while the individual factors are usually significant (O'Flaherty, 2002). The second group of the literature focus more on the individual factors such as illness, addictions, or incarceration histories. They support the policies to reduce the homeless by focusing at the drug abuses, mental healthcare and the poverty reduction.

The factors that have been used very often in the literature of homelessness and housing are the conditions in the housing market and housing affordability, economic condition such as poverty rate and unemployment, demographic composition such as percentage of single-person household (lack the protection offered by second wage earners), safety net, climate, and the state of mental illness in the area. Housing price inflation throughout the market has made the transition to home ownership more difficult and thus have increased competition for rental units, pushing the heavier burden on the poor household. Elliott and Krivo (1991) showed the empirical evaluation of the influences of several structural conditions on rate of homelessness in U.S. metropolitan areas. One of their significant 
factors determining the rate of homelessness is the availability of low-cost housing. They estimated the relationship between the percent of total 1984 population that was homeless and four groups of independent variables; lack of low income housing, poverty, economic conditions, mental healthcare and demographics. Their results showed that the homelessness rate is negatively correlated with the amount of low-rent housing and both measures of mental health expenditure. Green (1993) showed that there are a mismatch between incomes and rents in many parts of the country, implying that few vacant units were available at the low end of the market. Stojanovic et al. (1999) surveyed the housing patterns of homeless families after shelter exit in New York City and found that nearly half of persons who left shelter without a subsidized apartments returned to the shelter. Their study supports that the government subsidized housing is an effective policy to alleviate the homeless problem. Lee, PriceSparatlen, and Kanan (2003) studied the determinants of homelessness in metropolitan areas using 1990 census single night data for 335 metropolitan areas. They found that the median rent level and the percentage of single-person household have a dominant effect on homelessness rates. Honig and Filer (1993) assessed the causes of homelessness using various factors using cross-sectional data of the metropolitan areas in the United States in 1984. They found that an increase in one standard deviation in rents at the tenth percentile resulted in a predicted increased in homelessness of 78 persons per 100,000 population, or about $42 \%$ of the mean level of homelessness across the metropolitan areas. The other factors that significantly determined the homelessness is the growth in the private sector employment. Higher maximum Aid to Families with Dependent Children (AFDC) benefits were associated with lower rates of homelessness. Treatment of the mentally ill appeared to have had an impact on the incident of homelessness (Honig and Filer, 1993). Their findings indicate that homelessness has multiple causes, rooted in the housing markets, labor markets, and public policies regarding the treatment of the mentally ill and the low-income population.

\section{Data and Variables}

This study uses the combination of variables from both the housing market condition and the socioeconomic factors to estimate the determinants of the homelessness in the U.S. The descriptive statistics of the variables used in this study is shown in Table 2. On average (2007-2016), the homeless rate (total number per 10,000 population in the U.S. is 17. Average housing price index is 139 (base year is 2000). The average of rental vacancy rate or $\%$ of units ready for rent is $9 \%$. U.S residents pay around $\$ 6,145$ per year on average for rents. In terms of socio-economic factors, the poverty rate on average in the U.S. in the past ten years is around $13 \%$ with the income inequality GINI index at 0.45 .

Table 2. Descriptive Statistics of the Dependent and Independent Variables

\begin{tabular}{|l|l|l|c|}
\hline \multicolumn{1}{|c|}{ Variables } & \multicolumn{1}{|c|}{ Description } & Mean & $\begin{array}{c}\text { Standard } \\
\text { Deviation }\end{array}$ \\
\hline $\begin{array}{l}\text { Homelessness } \\
\text { Rate }\end{array}$ & $\begin{array}{l}\text { Point-In-Time number of homeless people/10,000 } \\
\text { population in each state, including sheltered and } \\
\text { unsheltered people experiencing homelessness on a } \\
\text { single night. } \\
\text { Source of } \text { data: } \\
\text { U.S. Department of Housing and Urban Development } \\
\text { Homelessness Data Exchange: http://www.hudhdx.info/ }\end{array}$ & 16.92587 & 9.346585 \\
\hline $\begin{array}{l}\text { Housing } \\
\text { Market } \\
\text { Factors }\end{array}$ & $\begin{array}{l}\text { Housing Price } \\
\text { Index (2000 } \\
\text { base) }\end{array}$ & $\begin{array}{l}\text { Indexes are all-transactions indexes calibrated using } \\
\text { appraisal values and sales prices for mortgages bought } \\
\text { or guaranteed by Fannie Mae and Freddie Mac. The } \\
\text { values reflect the base year being used (annual } \\
\text { appreciations are the same). The index value is } \\
\text { calculated using a base of 100 in 2000. } \\
\text { Source of data: }\end{array}$ & 139.3426 \\
\hline
\end{tabular}




\begin{tabular}{|c|c|c|c|}
\hline Variables & Description & Mean & $\begin{array}{l}\text { Standard } \\
\text { Deviation }\end{array}$ \\
\hline & $\begin{array}{l}\text { https://www.fhfa.gov/DataTools/Downloads/Pages/Hou } \\
\text { se-Price-Index-Datasets.aspx\#mpo }\end{array}$ & & \\
\hline $\begin{array}{l}\text { Rental Vacancy } \\
\text { Rate }\end{array}$ & $\begin{array}{l}\text { \% of the rental inventory which is vacant for rent. } \\
\text { Source of data: } \\
\text { U.S. Census Bureau: } \\
\text { https://www.census.gov/housing/hvs/data/ann16ind.htm } \\
1\end{array}$ & 8.945778 & 2.847621 \\
\hline Rents & $\begin{array}{l}\text { Annual per capita expenditure on housing and } \\
\text { household utilities per is used to represent the rental } \\
\text { rates in each state over time. } \\
\text { Source of data: } \\
\text { Bureau of Economic Analysis: www.bea.gov }\end{array}$ & 6145.828 & 2715242 \\
\hline $\begin{array}{l}\text { Supply of } \\
\text { Housing Units }\end{array}$ & $\begin{array}{l}\text { Annual estimates of housing units for the United States } \\
\text { by state } \\
\text { Source of data: } \\
\text { U.S. Census Bureau, Population Division } \\
\text { https://factfinder.census.gov/faces/tableservices/jsf/page } \\
\text { s/productview.xhtml?src=bkmk }\end{array}$ & $2,644,576$ & 2715242 \\
\hline \multicolumn{4}{|l|}{$\begin{array}{l}\text { Economic } \\
\text { Conditions }\end{array}$} \\
\hline Poverty Rate & $\begin{array}{l}\% \text { of people who have money income lower than the } \\
\text { threshold that vary by family size of total population of } \\
\text { each state. } \\
\text { Source of data: } \\
\text { U.S. Census Bureau: } \\
\text { https://www.census.gov/data/tables/time- } \\
\text { series/demo/income-poverty/historical-poverty- } \\
\text { people.html }\end{array}$ & 13.32500 & 3.354200 \\
\hline $\begin{array}{l}\text { Number of Job } \\
\text { Loss }\end{array}$ & $\begin{array}{l}\text { Number of job loss from the private firms in each state } \\
\text { Source of data: } \\
\text { U.S. Census Bureau QWI Explorer application }\end{array}$ & $108,946.1$ & 115804.1 \\
\hline $\begin{array}{l}\text { GINI Index of } \\
\text { Income } \\
\text { Inequality }\end{array}$ & $\begin{array}{l}\text { The GINI coefficient is a measure of inequality of a } \\
\text { distribution. } 0 \text { corresponds to perfect income equality } \\
\text { and } 1 \text { corresponds to perfect income inequality. } \\
\text { Source if data: } \\
\text { U.S. Census Bureau, } 2016 \text { American Community } \\
\text { Survey }\end{array}$ & 0.457301 & 0.020135 \\
\hline
\end{tabular}

After conducting the descriptive statistics, Washington DC shows an exceptional high homelessness rate. The outlier test has been conducted and the author decided to eliminate Washington DC out of the dataset.

Table 3. shows the cross-correlation among variables in the model. The homelessness rate in each state has a fairly strong positive correlations with housing price index with 2000 base (HPI) and the per capita consumption expenditure of housing which represent the rental rates. The housing price index has a strong positive correlation with the per capita consumption expenditure on housing and negative correlation with the rest of the variables. The rental vacancy rate has positive correlation with poverty and weak positive correlation with the number of job loss. Table 3. Also shows that here is no multicollinearily problem among the independent variables. 
Table 3. Cross-Correlation among Variables

\begin{tabular}{|c|c|c|c|c|c|c|}
\hline & $\begin{array}{c}\text { Homelessness } \\
\text { Rates }\end{array}$ & HPI & $\begin{array}{c}\text { Rental } \\
\text { Vacancy } \\
\text { Rates }\end{array}$ & Poverty & Job loss & $\begin{array}{c}\text { Personal } \\
\text { consumption } \\
\text { Expenditure } \\
\text { on Housing }\end{array}$ \\
\hline Homelessness Rates & 1.000000 & & & & & \\
\hline HPI & 0.429477 & 1.000000 & & & & \\
\hline Rental Vacancy Rates & -0.057308 & -0.255420 & 1.000000 & & & \\
\hline Poverty & 0.139636 & -0.244095 & 0.402249 & 1.000000 & & \\
\hline Job loss & -0.018061 & -0.041294 & 0.087397 & 0.126755 & 1.000000 & \\
\hline $\begin{array}{c}\text { Personal consumption } \\
\text { Expenditure on } \\
\text { Housing }\end{array}$ & 0.305296 & 0.476808 & -0.437944 & -0.398762 & 0.167688 & 1.000000 \\
\hline
\end{tabular}

\section{Model and Estimation Results}

The study use the ordinary least squares method (OLS) to estimate the national level, and OLS with fixed effects to estimate the regional and state models. Equation (1) shows the main model that the study uses.

$$
\begin{aligned}
& \text { Homelessness } s_{i i}=\beta_{\mathrm{L}}+\beta_{1} \log H \mu_{i ;}+\beta_{2} \log P C E_{i i}+\beta_{3} \text { RentalVacancyii } \\
& +\beta_{1} \operatorname{logHousingUnits}_{i i}+\beta_{5} \text { Povertylate }_{i j}+\beta_{\mathrm{i}} \text { logJobloss } \text { lo }_{i,}+\beta_{7} \text { GIN }_{i j} \\
& \left(+\beta_{\text {siui: }} \text { State }\right) \text { or }\left(+\beta_{\text {rejien }} \text { Region }\right)
\end{aligned}
$$

Where $i=2007-2016$ and $j=1-51$ (States in the U.S.)

The estimation results are shown in Table 4. For the overall U.S., all independent variables except the housing units can explain the variation in the homelessness rate by $35.29 \%$. The statistically significant coefficients for each variables have the expected signs. When the housing price index increases by $1 \%$ the homelessness is expected to increase by $0.58 \%$. When the personal expenditure on housing changes by $1 \%$, the homelessness rates will also change in the same direction by $1.16 \%$. The job loss and poverty rate have a statistically positive relationship with the homelessness. If the country experiences higher poverty rate and more job loss, the homelessness tends to rise. When the country has higher income equality (the GINI coefficient approaching 1), there tends to be less homeless individuals.

Table 4. Estimation Results

\begin{tabular}{|l|r|r|r|}
\hline \multicolumn{1}{|c|}{ Independent Variables } & Overall U.S. & Regional Level & \multicolumn{1}{c|}{ State Level } \\
\hline Constant & $-8.465799^{* *}$ & $-7.519781^{* *}$ & $-24.88214^{* *}$ \\
S.E. & $(1.150486)$ & $(1.306422)$ & $(12.07203)$ \\
\hline $\log$ (Housing Price Index & $0.583536^{* *}$ & $0.503547^{* *}$ & -0.140685 \\
2000 base) & $(0.139173)$ & $(0.141450)$ & $(0.123536)$ \\
S.E. & $1.160588^{* *}$ & $0.801444^{* *}$ & -0.306102 \\
\hline log(personal consumption & & & \\
expenditure on housing) & $(0.117610)$ & $(0.133299)$ & $(0.297289)$ \\
S.E. & $-0.015958^{* *}$ & 0.003875 & $0.024860^{* *}$ \\
\hline Rental vacancy rate (\%) & $(0.007482)$ & $(0.007398)$ & $(0.005706)$ \\
S.E. & -0.174772 & 0.069976 & $2.004461^{* *}$ \\
\hline log (estimated housing & & & \\
units) & $(0.118437)$ & $(0.112587)$ & $(0.975600)$ \\
S.E. & $0.061563 * *$ & $0.034102 * *$ & -0.000555 \\
\hline Poverty rate (\%) & $(0.008029)$ & $(0.008630)$ & $(0.006444)$ \\
S.E. & & & \\
\hline
\end{tabular}




\begin{tabular}{|c|c|c|c|}
\hline Independent Variables & Overall U.S. & Regional Level & State Level \\
\hline $\log$ (Number of Job loss) & $0.283129 * *$ & 0.023627 & $0.294473 * *$ \\
\hline S.E. & $(0.113843)$ & $(0.109119)$ & $(0.097900)$ \\
\hline $\begin{array}{l}\text { GINI Coefficient } \\
\text { S.E. }\end{array}$ & $\begin{array}{r}-6.783112 * * \\
(1.326157)\end{array}$ & $\begin{array}{r}-1.244973 \\
(1.417727)\end{array}$ & $\begin{array}{l}-2.766544^{*} \\
(1.555311)\end{array}$ \\
\hline $\begin{array}{l}\text { Northeast } \\
\text { S.E. }\end{array}$ & - & $\begin{array}{r}-0.455895^{* *} \\
(0.058640) \\
\end{array}$ & - \\
\hline $\begin{array}{l}\text { Southwest } \\
\text { S.E. }\end{array}$ & - & $\begin{array}{r}-0.508854 * * \\
(0.084433)\end{array}$ & - \\
\hline $\begin{array}{l}\text { Southeast } \\
\text { S.E. }\end{array}$ & - & $\begin{array}{r}-0.512681 * * \\
(0.077576)\end{array}$ & - \\
\hline $\begin{array}{l}\text { Midwest } \\
\text { S.E. }\end{array}$ & & $\begin{array}{r}-0.499524^{* * *} \\
(0.062332)\end{array}$ & - \\
\hline $\mathrm{R}^{2}$ & 0.352902 & 0.46645 & 0.890549 \\
\hline
\end{tabular}

*statistically significant at 10\% confidence level, $* *$ statistically significant at $5 \%$ confidence level

\section{Homeless in the Regional Level}

In the regional level of estimation, the study includes four dummy variables to represent five different regions in the U.S. The model presented regions include Northeast, Midwest, Southeast, Southwest, and the West (as reference region). The study found that the signs of every statistically significant coefficients stay the same as in the overall U.S. estimation. There are five different regions in the U.S. and the estimation results show that the characters of each region can explain the variation in the homelessness rates. The characteristics of each region may include the average temperature, number of big cities and metropolitan areas. The estimated result shows that housing price index, personal consumption expenditure on housing, poverty rate are statistically significant determinants of the homelessness rates in the regional level. Number of housing units, number of job loss and the rental vacancy rate cannot explain the homelessness in the regional level. The southeast region has the lowest intercept term which implies that the region's fitted line has started at the lower homelessness rates than the rest of the country. The West's fitted line starts at the higher homelessness rates compared the rest of the country.

\section{Homeless in the State Level}

For the estimation in the state level, the study uses the fixed effect panel least squares method to include the dummy variables for all states into the model and dropped the dummy variables for the regions. There are four variables that are statistically significant in the state level model: rental vacancy rates, housing units, number of job loss, and the GINI coefficients. When the rental vacancy rates, estimated housing units and poverty rates increase, the homelessness rate tends to rise. When the state has more equality in the income, the homelessness will fall. Interestingly, the housing price index and the personal expenditure of housing coefficients are no longer statistically significant. The result indicates that the housing price index might be captured in the fixed effects by state level. Table 5. shows the fixed effects from the state level estimation. Alaska and Vermont have the highest intercept term of the homelessness rates among 50 states. The lowest intercepts of homeless rates are in Texas and California.

Table 5. Cross-sectional (state) effects

\begin{tabular}{|c|r|c|c|}
\hline State & Effect & State & Effect \\
\hline AK & 4.335692 & MT & 2.927426 \\
\hline AL & -1.027602 & NC & -2.416318 \\
\hline AR & 0.133093 & ND & 3.495812 \\
\hline AZ & -1.101793 & NE & 1.831797 \\
\hline CA & -3.850730 & NH & 2.147352 \\
\hline CO & -0.158997 & NJ & -1.607256 \\
\hline CT & 0.283968 & NM & 1.393615 \\
\hline DE & 2.844434 & NV & 1.488106 \\
\hline FL & -3.325620 & NY & -2.507238 \\
\hline
\end{tabular}




\begin{tabular}{|c|c|c|c|}
\hline State & Effect & State & Effect \\
\hline GA & -1.889198 & OH & -2.997291 \\
\hline HI & 3.885837 & OK & -0.316113 \\
\hline IA & -0.011875 & OR & 1.134319 \\
\hline ID & 1.783822 & PA & -3.007625 \\
\hline IL & -2.945991 & RI & 2.857862 \\
\hline IN & -1.803170 & SC & -0.961411 \\
\hline KS & -0.026899 & SD & 2.918574 \\
\hline KY & -0.481644 & TN & -1.202371 \\
\hline LA & -0.439385 & TX & -4.291191 \\
\hline MA & -0.335070 & UT & 0.801615 \\
\hline MD & -0.666465 & VA & -1.957180 \\
\hline ME & 2.232125 & VT & 4.153130 \\
\hline MI & -2.423677 & WA & -0.447389 \\
\hline MN & -0.841756 & WI & -1.420180 \\
\hline MO & -1.337567 & WV & 1.146786 \\
\hline MS & -0.201572 & WY & 4.056288 \\
\hline & & &
\end{tabular}

\section{Conclusion}

Homelessness in the U.S. can reflect an overall decline in the nation's standard of living, the distortion of the housing market and the effectiveness of the government policies. The higher cost of living along with the unemployment brings economic hardship to the extremely poor individuals or families to the homelessness. This study confirms that housing market and housing affordability are important factors. The variation in the housing price, expenditure on rents, and the availability of the housing units can explain the homelessness rates across all states in the U.S. The other factors included in the models are socio-economic factors such as the poverty rate, number of job loss, and income inequality. In the state level, the availability of housing units, the rental vacancy rates, the number of job loss, and income inequality can explain the change in the homelessness rates. The housing price index, the expenditure on rents, poverty rates can determine the homeless rates in the national and the regional levels but not the state level. Table 6 . shows the determinants of the homelessness in each level.

Table 6. Summary of the Estimation Results

\begin{tabular}{|l|l|}
\hline National Level (without fixed effects) & Housing Price Index $(+)$ \\
& Personal Consumption Expenditure on Housing $(+)$ \\
& Rental Vacancy Rate $(-)$ \\
& Poverty $(+)$ \\
& Number of Job Loss $(+)$ \\
\hline Regional Level & Housing Price Index $(+)$ \\
& Personal Consumption Expenditure on Housing $(+)$ \\
& Poverty $(+)$ \\
\hline State Level & Rental Vacancy Rate $(-)$ \\
& Housing Units $(+)$ \\
& Number of Job Loss $(+)$ \\
\hline
\end{tabular}

\section{Policy Recommendation}

The estimation results confirms that both housing market conditions and socio-economic factors are the main determinants of homelessness in the U.S. To alleviate the problem the Federal government should monitor closely on the housing market conditions in term of prices, availability, affordability, and the rents. The state government should focus at supporting the efficiency in the rental markets, providing the public training programs to increase the skills for unemployed workers, and alleviating the income 
inequality. Subsidized housing can be an effective way to help individuals and families when they exit the shelter. There is also a limitation of the homelessness definition that prohibit the homeless shelters to help them. For example, people who are couch surfing or living off their cars are not considered homeless by the definition of U.S. Department of Housing and Urban Development. When these people are seeking help from the homeless shelter in the area, they will not be qualified to stay in the shelter. This fact is observed by the author's interview with the CEO of the homeless shelters in Duluth-Superior area. The immediate policy that the government can do is changing the definition of the homeless to be accurately reflected all people experiencing homeless problem.

\section{References}

Associated Press. 2017. America's Homeless Population Rises for the First Time in Years. Retrieved from https://www.usnews.com/news/us/articles/2017-12-06/us-homeless-count-rises-pushed-by-crisis-on-the-west-coast

Burt, M.M. 1993. Over the Edge: The Growth of Homelessness in the 1980s. New York: Russell Sage Foundation.

Elliot, M. and Krivo, L.J. 1991. "Structural Determinants of Homelessness in the United States." Social Problems 38(1): 113-131.

Federal Housing Finance Agency. 2018. Annual House Price Indexes. Retrieved from https://www.fhfa.gov/DataTools/Downloads/Pages/House-Price-Index-Datasets.aspx\#atvol

Honig, M. and Filer, R.K. 1993. "Causes of Intercity Variation in Homelessness.” American Economic Review 83(1): 248255.

Lee, B.A., Price-Spratlen, T \& Kanan, J.W. 2003. "Determinants of Homelessness in Metropolitan Areas.” Journal of Urban Affairs 25(3): 335-355.

Lowry, I.S. 1960. Filtering and housing standards. Land Economics 35: 362.370.

Malpezzi, S. and Green, R.K. 1996. "What Has Happened to the Bottom of the US Housing Market?" Urban Studies 33(10): 1807-1820.

National Alliance to End Homelessness. 2018. The State of Homelessness in America. Retrieved from https://endhomelessness.org/homelessness-in-america/homelessness-statistics/state-of-homelessness-report/.

National Alliance to End Homeless. 2018. Change in the HUD Definition of Homeless. Retrieved from https://endhomelessness.org/resource/changes-in-the-hud-definition-of-homeless/.

O'Flaherty, B. 1995. “An Economic Theory of Homelessness and Housing.” Journal of Housing Economics 4(1): 13-49.

O'Flaherty, B. 2002. "Causes of Homelessness: Understanding City-and Individual-Level Data”, Department of Economics Discussion Paper, 0102-59, Columbia University Academic Commons, Retrieved from https://doi.org/10.7916/D8571Q6R.

Quigley, J.M. and Raphael, S. 2001. "The Economics of Homelessness: The Evidence from North America." European Journal of Housing Policy 1(3): 323-336.

Stojanovic,D., Weitzman, B.C., Shinn, M., Labay, L.E., and Williams, N.P. 1999. "Tracing the Path Out of Homelessness: The Housing Patterns of Families After Exiting Shelter.” Journal of Community Psychology 27(2): 199-208.

U.S. Department of Housing and Urban Development. 2018. HUD Exchange: PIT and HIC Data Since 2007. Retrieved from https://www.hudexchange.info/resource/3031/pit-and-hic-data-since-2007/.

U.S. Census Bureau. 2018. Housing Vacancies and Home Ownership: Rental Vacancy Rate. Retrieved from https://www.census.gov/housing/hvs/data/ann16ind.html.

U.S. Department of Housing and Urban Development. 2018. Homelessness Data Exchange. Retrieved from http://www.hudhdx.info/.

Weicher, J.C. 1991. Housing policy and programs: a new strategy to alleviate poverty. Paper presented to the LaFollette Conference on U.S. Housing Policy. 